Louisiana State University

LSU Digital Commons

Faculty Publications

Department of Geology and Geophysics

$12-1-2002$

\title{
Tectonic and climatic evolution of the Arabian Sea region: An introduction
}

\author{
Peter D. Clift \\ Woods Hole Oceanographic Institution \\ Dick Kroon \\ Vrije Universiteit Amsterdam \\ Christoph Gaedicke \\ Bundesanstalt für Geowissenschaften und Rohstoffe \\ Jonathan Craig \\ Lasmo PlC
}

Follow this and additional works at: https://digitalcommons.Isu.edu/geo_pubs

\section{Recommended Citation}

Clift, P., Kroon, D., Gaedicke, C., \& Craig, J. (2002). Tectonic and climatic evolution of the Arabian Sea region: An introduction. Geological Society Special Publication, 195, 1-5. https://doi.org/10.1144/ GSL.SP.2002.195.01.01

This Article is brought to you for free and open access by the Department of Geology and Geophysics at LSU Digital Commons. It has been accepted for inclusion in Faculty Publications by an authorized administrator of LSU Digital Commons. For more information, please contact ir@lsu.edu. 


\title{
Tectonic and climatic evolution of the Arabian Sea region: an introduction
}

\author{
PETER D. CLIFT ${ }^{1}$, DICK KROON ${ }^{2}$, CHRISTOPH GAEDICKE ${ }^{3} \&$ \\ JONATHAN CRAIG ${ }^{4}$ \\ ${ }^{1}$ Woods Hole Oceanographic Institution, Woods Hole, MA 02543, USA \\ (e-mail:pclift@whoi.edu) \\ ${ }^{2}$ Institute of Earth Sciences, Free University Amsterdam, de Boelelaan 1085, $1081 \mathrm{HV}$ \\ Amsterdam, The Netherlands \\ ${ }^{3}$ Bundesanstalt für Geowissenschaften und Rohstoffe (BGR), Stilleweg 2, D-30655 Hannover, \\ Germany \\ ${ }^{4}$ Lasmo plc, 101 Bishops Gate, London EC2M 3XH, UK
}

The evolution of the global oceanic and atmospheric circulation systems has been affected by several forcing processes, with orbital variations being dominant on shorter geological time scales. Over longer periods of time $(>10 \mathrm{Ma})$ the tectonic evolution of the solid Earth has been recognized as the major control on the development of the global climate system. Tectonic activity acts in one of two different ways to influence regional and global climate. The earliest solid Earthclimatic interaction recognized was the effect that the opening and closure of oceanic gateways had on the circulation patterns in the global ocean. Major effects on regional and sometimes global climate have been attributed to such changes, e.g. closure of the Isthmus of Panama (Driscoll \& Haug 1998). Since the late 1980s a second form of climate-tectonic interaction has been recognized, involving the growth and erosion of orogenic belts. In this second category the Arabian Sea region must be considered the global type example.

Growth of the Himalaya and associated Tibetan Plateau is now believed to have substantially altered Cenozoic climate. Raymo et al. (1988) suggested that chemical erosion of the uplifting orogen resulted in the draw-down of atmospheric $\mathrm{CO}_{2}$, which was deposited as limestone, causing long-term global cooling, as a result of the reduction in this important greenhouse gas. Orogenic uplift is also believed to affect regional climate and in particular development of the monsoon. Summer heating of air above the Tibetan Plateau is known to have induced a strengthening of the monsoon (Manabe \& Terpstra, 1974), and so tectonic uplift of the plateau has been linked to strengthening of the monsoon (Raymo \& Ruddiman 1992; Molnar et al. 1993).
The Arabian Sea is the natural laboratory to study the interaction between orogenic growth and regional climate change. Ocean Drilling Program (ODP) sampling of pelagic sediments on the Oman margin has revealed a detailed history of monsoonal variability (Kroon et al. 1991; Prell et al. 1992), most notably an intensification of the monsoon at $8.5 \mathrm{Ma}$, as traced by the abundance of Globigerina bulloides and other eutrophic species, foraminifers associated with monsoon-induced coastal upwelling in the modern Arabian Sea. Initially this result appeared to correlate well with the start of extension on the Tibetan Plateau, an event that was linked to a period of rapid plateau uplift. Consequently, Harrison et al. (1992) and Molnar et al. (1993) proposed a direct correlation between rapid Tibetan uplift at that time and a strong SW monsoon and increased rainfall. Modelling studies support a shift of increased precipitation from Indochina toward the Himalayas and a strengthening of the Asian monsoon during late Tertiary time, separate from the strengthening at $8.5 \mathrm{Ma}$ (Fluteau et al. 1999).

More recently, fieldwork in Tibet has complicated our ideas about the timing of uplift, with some workers indicating at least southern Tibet reaching maximum elevation at c. $19 \mathrm{Ma}$ (Williams et al. 2001), whereas others suggest rapid uplift of the northern plateau during Pliocene time (Zheng et al. 2000). Work on the monsoon also continues to change our understanding of the climatic evolution of South Asia. Derry \& France-Lanord (1997) proposed that the 87 Ma period in fact represented a weak monsoon, with greater regional aridity rather than the standard image of greater precipitation. Clearly much work remains in defining the timing of the SW monsoon and the timing of tectonism in Tibet. 
Downloaded from http://sp.lyellcollection.org/ at Louisiana State University on November 29, 2021

\section{Testing climate-tectonic models?}

Despite the current debate, the Arabian Sea has several features that make it the best area globally to examine solid Earth-climatic interactions. The climatic signal is strong, especially with regard to the monsoon, and the rates of sedimentation are often high, allowing detailed palaeoceanographic records to be reconstructed. The Indus River has a large output, equivalent to that of the Mississippi River, and carries an erosional record of the high topography north of the High Himalaya, i.e. the Karakoram and western Tibet, which are the regions responsible for the monsoon. The modern climate of arid conditions, punctuated by heavy seasonal rains, contributes to enhancing erosion, the products of which can be found interbedded with dateable fossiliferous sediments in the Indus Fan. The western Himalaya and Karakoram have been the focus of much recent fieldwork, often involving high-resolution radiometric dating of basement units. This means that the thermal and tectonic development of these ranges can be accurately correlated with the marine records. Indeed, the very fact that the Arabian Sea is surrounded on three sides by land, often arid and with good exposure, makes this an ideal area to attempt linked marine and land-based field experiments.

Much work remains to be done in understanding the tectonic and climatic evolution of the Arabian Sea area. Efforts are now under way to expand our sampling on- and offshore so as to understand the temporal variations in climate, erosion and tectonism. Such efforts necessarily require international collaboration between researchers within the region and elsewhere. Additional marine geophysical surveys and deep scientific drilling are required in the Arabian Sea to construct the detailed records required to quantify the nature of solid Earth-climatic coupling. None the less, much has been achieved by a series of cruises and field campaigns over the last 10 years, since the last major review of the region. It was the desire to bring together workers spread across many countries and disciplines that prompted the special meeting of the Geological Society, where much of the work published here was presented.

The development of the Arabian Sea before India-Asia collision is reconstructed by three of the papers presented here. Royer et al. use a compilation of marine geophysical data to demonstrate that spreading in the Arabian Sea at 61$46 \mathrm{Ma}$ has been affected by a series of successive ridge propagation events along the Carlsberg Ridge, and that the Arabia-India plate boundary was located west of the Owen Ridge along the
Oman margin during most of Paleogene time. Chaubey et al. analyse marine magnetic anomaly patterns, and conclude that not only was Paleogene spreading very asymmetric, with the Arabian Sea accreting much faster than the Somali Basin, but also India-Somali motion slowed rapidly after $52 \mathrm{Ma}$. The evolution of the passive Indian margin before collision with Asia is described by Smewing $\boldsymbol{e t} \boldsymbol{a l}$. in a stratigraphic study of the southern Kirthar Fold Belt in Pakistan. Rift shoulder uplift and erosion of Middle Jurassic limestones dates the separation of India from East Africa. Subsequently, two phases of ophiolite emplacement are recognized, in Late Cretaceous and Early Tertiary time. Late Cretaceous (Campanian and Maastrichtian) submarine fans are interpreted to reflect thermal uplift of India as a result of the Deccan Plume. Subsequently, Middle Eocene northerlyderived clastic sediments from the early Himalaya constrain the age of collision in this region. The Kirthar Fold Belt is interpreted as an offshore equivalent of the Murray Ridge, which is underlain by thinned continental crust.

The slowing of India-Asia convergence after $52 \mathrm{Ma}$ described by Chaubey $\boldsymbol{e t} \boldsymbol{a l}$. is broadly in accord with the evolving sedimentary character within the Asian forearc basin revealed by Clift $e t$ $a l$. This study shows an influx of ophiolitic and carbonate platform material from a deformed Indian margin into the Jurutze forearc basin no later than Ypresian time $(>49 \mathrm{Ma})$. The subsequent deposition of the alluvial Indus Group in the Indus Suture in Ladakh has been linked by Clift to the earliest activity of a palaeo-Indus River, which flowed into a delta in the Katawaz Basin of western Pakistan and Afghanistan by Early Eocene time, and must have reached the Arabian Sea by Mid-Eocene time. Some of that material has subsequently been accreted to the active margin of Asia. McCall shows that the Makran Accretionary Complex contains large volumes of Paleogene turbidites that were added to that margin, and may represent a palaeo-Indus Fan, in addition to the material still found in the Arabian Sea. Clift et al. show that the Indus Group Basin was inverted no later than $14 \mathrm{Ma}$, probably close to the time of tectonic uplift along the Murray Ridge (20 Ma), but that the Indus River has remained stationary in the suture since that time.

Clift presents a sediment budget for the Indus Fan that shows peak sedimentation rates in midMiocene time accompanied by channel-levee accumulation on the mid-fan, during a period of strong tectonic activity in the Karakoram, and possibly linked to an early initiation of the SW monsoon. Closer to the coast, Daley \& Alam provide a review of the seismic stratigraphy of the 
Downloaded from http://sp.lyellcollection.org/ at Louisiana State University on November 29, 2021

offshore Indus Basin (Pakistan Shelf), highlighting the existence of two distinct phases of canyon development on the upper part of the Indus Fan: one in Early Miocene time and the other in PlioPleistocene time. Both phases are interpreted as relating to pulses of tectonic activity in the collision zone between the Indo-Pakistan and Eurasian plates.

The regional stratigraphy of the northern Arabian Sea is defined by Gaedicke $\boldsymbol{e t} \boldsymbol{a l}$., who employ seismic data to construct a four-part stratigraphy to the Indus Fan and Gulf of Oman. They show that opening of the Gulf of Aden in mid- to late Miocene time caused a reorganization of the plates and subsequent tilting of the oceanic crust of the Arabian Plate toward the Makran subduction zone, thus generating the regional ' $\mathrm{M}$ unconformity'. Uplift of the Murray Ridge during late Miocene to early Pliocene time has caused a separation in sedimentation between the Gulf of Oman and the Arabian Sea, with the modern Indus Fan prevented from flowing westward by the Murray Ridge. Burgath et al. provide sedimentary evidence that the Murray Ridge was uplifted close to sea level in late Miocene to early Pliocene time and subsequently subsided to modern depths. These workers also present geochemical data derived from samples for the volcanic and plutonic basement to the Murray Ridge demonstrating an origin within a Mesozoic Neotethyan active margin setting.

\section{Pleistocene-Holocene sedimentation}

Glacial sea-level lowstand periods are identified by Williams \& Walkden as times when the Persian Gulf was subaerially exposed, allowing changes in sea level to be quantified. Sediments deposited during the last interglacial contain evidence for two highstands during this period, peaking at around 1.5 and $6 \mathrm{~m}$ above present sea level. Following the second highstand, sea level fell to more than $23 \mathrm{~m}$ below present level. Palaeocurrent directions indicate that during the last interglacial $(125 \mathrm{ka})$ the prevailing wind blew from the NE. Evidence for a pluvial episode during this period is provided by palaeokarstic pits, believed to represent the former positions of trees or large plants.

Glennie $\boldsymbol{e t} \boldsymbol{a l}$. provide an overview of the development of the distribution of sand dunes over the southern half of Arabia during the Quaternary period. They discuss the expansion and contraction of deserts and their relationship to changes in climate. Two wind systems influenced desert formation: the northern 'Shamal' and the strong winds of the SW monsoon. The Shamal was particularly active during the cold parts of the
Quaternary period and the SW monsoon was active during interglacial periods.

Upper Holocene sediments cored from the Pakistan margin within the oxygen minimum zone are used by Von Rad $e$ al. to show a varving related to seasonal river flood events. A climate with reduced precipitation and river runoff, possibly 'winter monsoon' dominated, is recognized at $5600-4700$ a $b p$ on the basis of the thin varves, whereas other periods characterized by thicker varves document wetter periods, with summer-monsoon domination. These workers relate the cyclicity found in the varved sequence to lunar cycles, which result in variations in the amplitudes of tides, which in turn may have controlled sediment redeposition. Also, Luckge et al. describe Holocene varved sediments and their causes, and calibrate the variations in thickness of the varves to meteorological records such as rainfall.

In a separate contribution, Von Rad et al. discuss the discovery of a discrete ash layer derived from the Indonesian volcano Toba $(70 \pm$ $4 \mathrm{ka}$ ) and recovered from sediments deposited in the oxygen minimum zone offshore the Indus delta. In addition, two rhyolitic ash layers are dated at AD 1885-1900 and 1815-1830. The glass shards were probably derived from eruptions of Indonesian volcanoes, although it is not possible to correlate these two ashes with well-known historical eruptions. A complete, high-resolution stratigraphic record of the past $75 \mathrm{ka}$, with 21 interstadials or Dansgaard-Oeschger cycles and equivalents of Heinrich events $\mathrm{H} 1-\mathrm{H} 6$ is recognized. Rapid climate oscillations with periods around $1.5 \mathrm{ka}$ can be tuned to the $\delta^{18} \mathrm{O}$ record of a Bay of Bengal core and to the GISP-2 ice core from Greenland. Changes in the intensity of the Indian summer monsoon are tightly coupled with suborbital climate oscillations in the Northern Hemisphere.

The late glacial-Holocene evolution of the monsoon is reconstructed by Jung et al . using cores from the Arabian Sea offshore Somalia. Using a multiproxy approach they determine that bulk sediment chemistry, most notably $\mathrm{Ba} / \mathrm{Al}$, provides the best record of productivity associated with monsoon strength. Foraminifer-based records conflict with the sediment chemistry on centennial and millennial time scales, indicating that more than upwelling controls their productivity. Dissolution on the sea floor has affected foraminiferal abundances during the transition period. During glacial times upwelling and productivity were stronger during the winter NE monsoon, as opposed to the modern situation, where production is strongest during the summer SW monsoon.

Particle flux, sediment trap data, in the NE Arabian Sea are described by Schulz et al. Those 
Downloaded from http://sp.lyellcollection.org/ at Louisiana State University on November 29, 2021

workers document that the particle flux, including biota, in the NE Arabian Sea is determined by sediment resuspension and winter productivity rather than by summer upwelling. This is in contrast to numerous sediment trap observations in the western Arabian Sea. The new evidence is used to reconstruct the seasonal intensity of both monsoons for the past $25 \mathrm{ka}$. Schultz et al. use planktonic foraminiferal abundances for monsoon intensity in a core with a high temporal resolution. The NE monsoon peaked during the stadial phases and the SW monsoon during the Holocene period. Combined sediment trap and box core records of nitrogen isotopes $\left(\delta^{15} \mathrm{~N}\right)$ in organic matter are studied by Brummer et al. Complex patterns of annual nitrogen fluxes and $\delta^{15} \mathrm{~N}$ are described, and their fate in the sediments. Upwelling processes have a strong effect on the $\delta^{15} \mathrm{~N}$ of settling nitrogen. Freshly upwelled waters show minima in $\mathrm{d}^{15} \mathrm{~N}$, and maxima are found in stratified waters. Also, diagenesis is dicussed as a potential source for altering the primary signal.

Staubwasser \& Dulski reconstruct the earlymid-Holocene evolution of the oxygen minimum zone in the Arabian Sea by using a trace metal proxy. Century-scale fluctuations are recorded in the laminated sediments off Pakistan. Complex ventilation patterns of the subsurface waters include lateral advection from Central Indian Water and ventilation by winter surface convection in the northern Arabian Sea.

Stow et al. describe shallow cores from the upper slope, mid-slope and the abyssal plain offshore the Makran. They employ an oxygen isotope stratigraphy to provide an age determination for statistical analyses. The upper $5-14 \mathrm{~m}$ of sediment is dominated by fine-grained, thin turbidites, averaging 5-10 turbidite events per metre of section, or one turbidite event per $200-300 \mathrm{a}$. The range of turbidite bed thicknesses is typical for beds triggered by seismicity on active margins. The lateral distribution of both turbidites and hemipelagites is influenced by sediment focusing along pathways between slope basins. At a larger scale, climate, sea level and tectonic effects have all controlled the margin sedimentation.

Two papers discuss the ecology of plankton groups in the Arabian Sea and their potential as 'proxies' in the sediments. Wendler et al. discuss abundances of calcareous dinoflagellate cyst species in surface sediment samples, and these are compared with environmental parameters in the upper water column. Certain assemblages can be clearly correlated with temperature and nutrient levels, particularly in the SW Arabian Sea. In the NE Arabian Sea diagenetic processes must be taken into account in interpreting sediment assemblages. Peeters \& Brummer record the faunal composition and depth habitats of extant planktonic foraminifers by using plankton tows. The temporal distribution of assemblages of planktonic foraminifers is associated with the hydrography of the area, which is in turn controlled by the monsoon system. Highest abundances of eutrophic species occur during the upwelling phase triggered by the SW monsoon. Vertical abundance profiles in the water column are recorded to document depth habitats of individual species. This is important for interpretations of stable isotope studies using the shells of the planktonic foraminifers in sediments.

\section{Neotectonics}

The Arabian Sea region is still involved in the active deformation associated with India-Asia convergence and opening of the Red Sea and Gulf of Aden. In a review of this activity, Vita Finzi describes the Holocene record on the coasts of the Arabian Sea and interprets it in the context of the interaction between the Indian, Arabian and Eurasian plates. Marine terraces from the Makran margin show infrequent but vigorous coseismic uplift, similar to that seen in other accretionary subduction settings. Vita Finzi notes a landward rotation of the imbricate faults along which shortening is distributed. The lack of significant Holocene deformation on the SE coast of the Arabian peninsula is consistent with its position parallel to a transform, although large-scale buckling may be occurring at the Straits of Hormuz. Localized uplift on the SW of India represents compressional buckling related to India-Asia collision.

Sattarzadeh et al. examine the nature of folding in the Zagros Mountains as a result of the enhanced Pliocene deformation caused by faster Arabia-Asia convergence driven by opening of the Red Sea. The deformation in the Zagros is controlled by plate velocity and the regional stratigraphy, which is composed of four mechanically contrasting litho-structural units overlying a rigid basement. The sedimentary cover and the underlying metamorphic basement decouple along an important detachment horizon, the Hormuz Salt Formation. The uneven thickness and distribution of the Hormuz Salt plays a key role in determining the geometry of the deformation belt. The median surface of the fold belt has an asymmetric topography, its elevation ascending northeastward in a series of steps, consistent with neotectonic field evidence for serial folding and imbrication of the footwall.

Delisle \& Berner present a numerical model of the geothermal field of the Makran accretionary prism, which suggests that conductive heat transport is dominant and that there is little contribu- 
tion from fluid flow or frictional heat. They demonstrate that gas hydrate layers in the accretionary prism act as a very effective seal to the upward flow of fluids in water depths greater than $800 \mathrm{~m}$, but that they break down when uplifted out of the gas hydrate stability field into shallower and warmer water.

The papers in the volume arise from a special meeting of the Tectonic Studies, Marine Studies and Petroleum Groups of the Geological Society of London, held at the Geological Society, Burlington House, Piccadilly, on 4-5 April 2001. The meeting was convened by Peter Clift, Christoph Gaedicke, Jonathan Craig and Dirk Kroon. Lasmo UK plc and the Geological Society are thanked for their partial financial support of the meeting, proceeds from which helped cover the costs of colour figures and fold-outs in this publication. Chryseis Fox is thanked for creating and maintaining the related web pages.

The editors wish to acknowledge reviews by the following geoscientists: A. Beach, D. Benn, C. Betzler, J. P. Burg, S. Carey, S. Clemens, R. Coleman, P. D. Clift, T. Daley, K. Darling, P. Degnan, P. DeMenocal, R. Edwards, P. Friend, R. Ganeshram, E. Garzanti, E. Gnos, R. Graham, R. Harland, P. Hildebrand, M. Higginson, F. Jansen, G. Jones, C. Kendall, M. Khan, E. Kirby, N. Kukowski, F. Marret, K. McIntyre, J. McManus, P. Miles, T. Minshull, G. Mountain, N. Nowaczyk, F. Peeters, J. Pike, M. Prins, G. J. Reichart, J. J. G. Reijmer, L. R. Sautter, B. Schreckenberger, D. Schelling, R. Schneider, M. P. Searle, P. Sharland, A. D. Singh, F. Sirocko, J. Smewing, S. Swift, A. H. F. Robertson, E. Uchupi, J. Warburton, R. Whittington, C. Vita Finzi, U. von Rad.

\section{References}

DerRy, L.A. \& France-Lanord, C. 1997. Himalayan weathering and erosion fluxes; climate and tectonic controls. In: RudDiman, W.F. (ed.) Tectonic Uplift and Climate Change. Plenum, New York, 289-312.

Driscoll, N.W. \& HAUG, G.H. 1998. A short circuit in thermohaline circulation; a cause for Northern Hemisphere glaciation? Science, 282, 436-438.
Fluteau, F., Ramstein, G. \& Besse, J. 1999. Simulating the evolution of the Asian and African monsoons during the past $30 \mathrm{Myr}$ using an atmospheric general circulation model. Journal of Geophysical Research, 104, 11995-12018.

Kroon, D., Steens, T. \& Troelstra, S.R. et al. 1991. Onset of monsoonal related upwelling in the western Arabian Sea as revealed by planktonic foraminifers. In: Prell, W.L. \& NiItsuma, N. (eds) Proceedings of the Ocean Drilling Program, Scientific Results, 117. Ocean Drilling Program, College Station, TX, 257-263.

Harrison, T.M., Copeland, P., KIDD, W.S.F. \& Yin, A. 1992. Raising Tibet. Science, 255, 1663-1670.

Manabe, S. \& Terpstra, T.B. 1974. The effects of mountains on the general circulation of the atmosphere as identified by numerical experiments. Journal of Atmospheric Scences, 31, 3-42.

Molnar, P., England, P. \& Martinod, J. 1993. Mantle dynamics, the uplift of the Tibetan Plateau, and the Indian monsoon. Reviews in Geophysics, 31, 357-396.

Prell, W.L., Murray, D.W., Clemens, S.C. \& AnderSON, D.M. 1992. Evolution and variability of the Indian Ocean summer monsoon: evidence from the western Arabian Sea drilling program. In: DunCAN, R.A., REA, D.K., KIDD, R.B., VON RAD, U. \& WEISSEL, J.K. (eds) Synthesis of Results from Scientific Drilling in the Indian Ocean. Geophysical Monograph, American Geophysical Union, 70, 447-469.

Raymo, M.E., Ruddiman, W.F. \& Froelich, P. 1988. Influence of late Cenozoic mountain building on ocean geochemical cycles. Geology, 16, 649-653.

RAYMO, M.E. \& RuddimaN, W.F. 1992. Tectonic forcing of the late Cenozoic climate. Nature, 359 , 117-122.

Williams, H., Turner, S., Kelley, S. \& Harris, N. 2001. Age and composition of dikes in southern Tibet: new constraints on the timing of east-west extension and its relations to post-collisional volcanism. Geology, 29, 339-342.

Zheng, H., Powell, C.M., AN, Z., Zhou, J. \& Dong, G. 2000. Pliocene uplift of the northern Tibetan Plateau. Geology, 28, 715-718. 